\title{
Assessing toxicity of metal contaminated soil from glassworks sites with a battery of biotests
}

\section{Hagner, M.}

2018-02-01

Hagner , M , Romantschuk, M , Penttinen , O -P , Egfors , A , Marchand , C \& Augustsson , A 2018 , ' Assessing toxicity of metal contaminated soil from glassworks sites with a battery of biotests ' , The Science of the Total Environment, vol. 613 , pp. 30-38 . https://doi.org/10.1016/j.scitotenv.2017.08

http://hdl.handle.net/10138/308076

https://doi.org/10.1016/j.scitotenv.2017.08.121

cc_by_nc_nd

acceptedVersion

Downloaded from Helda, University of Helsinki institutional repository.

This is an electronic reprint of the original article.

This reprint may differ from the original in pagination and typographic detail.

Please cite the original version. 
1 Assessing toxicity of metal contaminated soil from glassworks sites with a battery of biotests

Hagner $M^{\mathrm{a}, \mathrm{b}}$, Romantschuk $\mathrm{M}^{\mathrm{a}, \mathrm{c}}$, Penttinen O-Pa, Egfors $\mathrm{A}^{\mathrm{d}}$, Marchand $\mathrm{C}^{\mathrm{d}}$, Augustsson $\mathrm{A}^{\mathrm{d} *}$

${ }^{a}$ Department of Enviromental Sciences, University of Helsinki, Lahti, Finland.

${ }^{\mathrm{b}}$ Natural Resources Institute Finland (Luke), Jokioinen, Finland

${ }^{\mathrm{c}}$ Institute of Environmental Sciences, Kazan Federal University, Kazan, Russia.

${ }^{\mathrm{d}}$ Department Biology and Environmental Science, Linnaeus University, Kalmar, Sweden.

*Corresponding author at: Department of Biology and Environmental Science, Linnaeus University, SE-391 82 Kalmar, Sweden. E-mail: anna.augustsson@lnu.se

\section{Abstract}

The present study addresses toxicological properties of metal contaminated soils, using glassworks sites in south-eastern Sweden as study objects. Soil from five selected glassworks sites as well as from nearby reference areas were analyzed for total and water-soluble metal concentrations and general geochemical parameters. A battery of biotests was then applied to assess the toxicity of the glassworks soil environments: a test of phytotoxicity with garden cress (Lepidium sativum); the BioTox $^{\mathrm{TM}}$ test for toxicity to bacteria using Vibrio fischeri; and analyses of abundancies and biomass of nematodes and enchytraeids. The glassworks- and reference areas were comparable with respect to $\mathrm{pH}$ and the content of organic matter and nutrients $(\mathrm{C}, \mathrm{N}, \mathrm{P})$, but total metal concentrations ( $\mathrm{Pb}, \mathrm{As}, \mathrm{Ba}, \mathrm{Cd}$ and $\mathrm{Zn}$ ) were significantly higher at the former sites. Higher metal concentrations in the water-soluble fraction were also observed, even though these concentrations were low compared to the total ones. Nevertheless, toxicity of the glassworks soils was not detected by the two ex situ tests; inhibition of light emission by $V$. fischeri could not be seen, nor was an effect seen on the growth of L. sativum. A decrease in enchytraeid and nematode abundance and biomass was, however, observed for the landfill soils as compared to reference soils, implying in situ toxicity to soil-inhabiting organisms. The confirmation of in situ bioavailability and negative 
Introduction

There are many sites that have been contaminated by metals released from past industrial activities, and metal contamination threatens the well-being of all components of the biosphere. Even though it is well known that high total concentrations may not always translate into high mobility, bioavailability and toxicity (Kördel et al. 2013; McLaughlin et al. 2000), risks at contaminated sites are often assessed based on analyses of total concentrations, sometimes complemented with weaker extractions that dissolve only the potentially bioavailable fraction. However, the potential for environmental hazards is better understood when chemical analyses are complemented with biotests, as organisms are only sensitive to the truly bioavailable fraction of metals (Garcia-Lorenzo et al. 2009; Römbke et al. 2005; Karjalainen et al. 2009). Biological tests could also integrate the effects of mixtures and their bioavailability and therefore provide a useful tool for site-specific assessment of actual ecological risks.

The long-lasting production of glass in south-eastern Sweden is one example of industrial activity, where the local soil environment has become severily contaminated over time, and where adverse health effects are now seen among local residents. Better understanding of soil toxicity properties is thus highly relevant at the Swedish glassworks sites. The main contamination occurred during the 1970s and earlier, when unsorted waste and crushed glass were thrown in a pile near the glassworks (Falk et al. 2005). A compilation of data from previous site investigations, available from the Kalmar and Kronoberg County Administrative Boards (2016), reveals maximum total concentrations in glassworks soils of the region (or rather soil with a varying mix of glass waste) of $16900 \mathrm{mg} \mathrm{kg}^{-1} \mathrm{~Pb}, 180 \mathrm{mg} \mathrm{kg}^{-1} \mathrm{Cd}$ and $2600 \mathrm{mg} \mathrm{kg}^{-1}$ As. It has also been shown that soils of private gardens around the glassworks may contain metal concentrations of the same magnitude as the glassworks properties, that there is a positive correlation between metal contamination and metal concentration in homegrown vegetables, and that consumption of these vegetables is a risk factor (Augustsson et al. 2015; Uddh-Söderberg et al. 2015). Recent findings also imply that residents living near glassworks in the area are at an increased risk of developing cancer (Nyqvist et al. 2017).

When turning from soil contamination to toxicology, a battery of toxicity tests with species of varying sensitivities and exposure pathways is recommended (Karjalainen et al. 2009). The suitability of biotests, such as the Phytotoxkit (to test plants) and Microtox ${ }^{\circledR} /$ BioTox $^{\mathrm{TM}}$ (bacterial 
test), in the assessment of toxicity of bottom sediments, composts, sewage sludge, and for example mining activity contaminated soils, has been proven in several studies (Boularbah et al. 2006a, b; Czerniawska-Kusza and Kusza 2011; Mamindy-Pajany et al. 2011; Loureiro et al. 2005; Dubova and Zarina 2004). Plants are essential primary food producers of ecosystems and thus it is important to identify the magnitude of the toxic effects on plants (Garcia-Lorenzo et al. 2009). Also, bacteria play a crucial role, being decomposers in the environment (Kahru et al. 2005). Other key organisms are enchytraeids and nematodes (Didden and Römbke 2001). Especially enchytraeids are sensitive to environmental stresses and the presence and species composition of enchytraeid worms have therefore been suggested for use as indicators of metal toxicity (Kapusta and Sobczyk 2015).

The aim of this study was to evaluate toxicity of glasswork contaminated soil. It was done by two ex situ tests: using a) a test of phytotoxicity with garden cress (Lepidium sativum), and b) the BioTox $^{\mathrm{TM}}$ test for toxicity to bacteria using the bioluminescent bacterium Vibrio fischeri as test organism. A bioassay was also performed by measuring the abundancies of soil-inhabiting nematodes and enchytraeids. In contrast to standardised laboratory tests, the latter approach reflects the in situ situation of the soil animals and the effect of their exposure to the contaminant metals.

Materials and methods

Study region

Five typical glassworks sites in the glassworks region of south-eastern Sweden were selected for the present study: Johansfors, Bergdala, Kosta, Orrefors and Målerås (Fig. 1). Production at all these sites has included artistic and crystal glass. The major raw materials in the glass production were silica quartz, calcite, feldspar and oxides of several metals, such as $\mathrm{As}, \mathrm{Cd}, \mathrm{Co}, \mathrm{Cr}, \mathrm{Cu}, \mathrm{Ni}, \mathrm{Pb}, \mathrm{Sb}$ and Zn (Hermelin and Welander 1986; Magnusson 1971; Månsson and Carlsson 2002). The volume of contaminated soil and landfill materials at the sites varies from a few thousand cubic metres to approximately $100000 \mathrm{~m}^{3}$, with high concentrations in particular of $\mathrm{Pb}$ and As (Fanger et al. 2004; Bergelin et al. 2006; Håkansson and Ländell 2006; Werkelin and Gustavsson 2006). Production is still running in Bergdala, Kosta, Målerås and Johansfors, but only on a small scale at the latter. The factory in Orrefors was closed down in 2013. However, most of the landfills were decommissioned in the late 1970s and have since been untouched while natural vegetation has been established and soils formed. The dominating tree species of the region are spruce and pine, and the natural soils typically show a podzolized profile. The quaternary deposits are dominated by sandy tills with a 
mineralogy that reflects the local granitic bedrock. One particularly relevant feature in this area is

103 the relatively high geogenic concentrations of Pb (SGU 2014). Mean January and July temperatures 104 in the study area are $-2.0^{\circ} \mathrm{C}$ and $17.0^{\circ} \mathrm{C}$, respectively, and the mean annual precipitation is approximately $700 \mathrm{~mm}$ (based on data from 2006 to 2015; SMHI 2016).

106

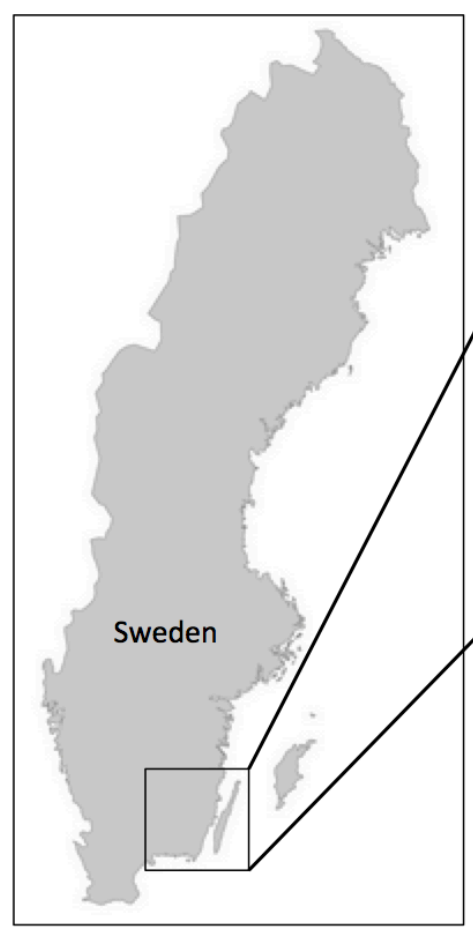

$13^{4} 5$

2

1. Bergdala (N: 6301021, E: 1464350)*

2. Johansfors (N: 6285482, E: 1483857)*

3. Kosta (N: 6302792, E: 1474995)*

4. Målerås (N: 6309860, E: 1485361)*

5. Orrefors (N: 6301709, E: 1496450)*

* Coordinates according to the Swedish format RT90

Fig. 1. Location of the five glassworks sites in southeastern Sweden.

\section{Sampling and chemical analyses of soils}

Soil samples were collected in October 2015. At each of the five selected glassworks sites, samples were taken both from the main landfill and from a nearby (within a few hundred metres) reference area. The reference area of each glassworks site was selected on-site based on the criteria: 1) similar vegetation characteristics i.e. type of ground cover and dominating tree species, and 2) similar natural soil characteristics (based on assessment in the field, e.g. a rough estimate of soil grain size, colour, approximate content of organic matter (OM) etc.). At each study site, five samples (approximately $5 \mathrm{~L}$ each) were collected from the landfill area, and five were taken from the reference area. This gave in total 50 samples, each taken from a unique hand dug pit as a composite sample from 0-20 cm depth (after the upper vegetative layer of loose litter and mosses had been removed). Samples were homogenized thoroughly but gently by hand and stored at $4^{\circ} \mathrm{C}$ until analysis. During the first week following sampling, a subset of the (unsieved) fresh material was 
used for determination of nematodes and enchytraeids (see Toxicity studies). The soil moisture (dry matter $=\mathrm{DM})$ was determined after drying $20 \mathrm{~g}$ of soil at $105^{\circ} \mathrm{C}$ for $24 \mathrm{~h}($ Standard ASTM D2216, ASTM 2010). The remaining material was air dried and sifted through a sieve with a $2 \mathrm{~mm}$ mesh. In soil prepared this way, basic soil properties were determined. Soil OM content was measured as the ignition loss $\left(4 \mathrm{~h}, 550^{\circ} \mathrm{C}\right.$; Radojević and Bashkin 2006). Electrical conductivity (EC) was measured using the WTW Cond330i meter, and $\mathrm{pH}$ was determined on a 1:2.5 (v/v) soil:distilled water suspension with a Mettler Delta $340 \mathrm{pH}$ meter according to the ISO 10390 standard (ISO 2005). Total nitrogen (tot-N) and carbon (tot-C) were analysed using a LECO CNS-analyser (Table 1).

The total concentrations of phosphorus (tot-P) and metal(loid)s (Ag, As, $\mathrm{Ba}, \mathrm{Cd}, \mathrm{Co}, \mathrm{Cr}, \mathrm{Cu}, \mathrm{Hg}$, $\mathrm{Ni}, \mathrm{Pb}, \mathrm{V}, \mathrm{Sn}, \mathrm{Mo}, \mathrm{Sb}, \mathrm{Zn})$ in the $<2 \mathrm{~mm}$ soil fraction were determined with inductively coupled plasma sector field mass spectrometry (ICP-SFMS) at the commercial Swedish laboratory ALS Scandinavia. The ICP-SFMS analyses followed the protocols of SS EN ISO 17294-1 and the US Environmental Protection Agency's (EPA's) method 200.8. Before analysis, soil samples were dried at $50^{\circ} \mathrm{C}$ and a $0.5 \mathrm{~g}$ sub-portion of the dried material was digested with $5.0 \mathrm{~mL}$ concentrated nitric acid $\left(\mathrm{HNO}_{3}\right)$ and $0.5 \mathrm{~mL}$ hydrogen peroxide $\left(\mathrm{H}_{2} \mathrm{O}_{2}\right)$ in closed Teflon vessels in a highpressure microwave oven. The received concentrations can be viewed as total, or pseudo-total. To get an efficient extraction of $\mathrm{Sb}$, the addition of hydrochloric acid $(\mathrm{HCl})$ is needed (Hjortenkrans et al. 2009). This element was therefore determined after an aqua regia extraction, where a $0.5 \mathrm{~g}$ subportion of the material was digested using $7.5 \mathrm{~mL}$ concentrated $\mathrm{HCl}$ and $2.5 \mathrm{~mL}$ concentrated $\mathrm{HNO}_{3}$. All chemicals used were of analytical grade quality.

Extracts of water-soluble metals (referred to as $\mathrm{H}_{2} \mathrm{O}$-metals throughout the paper) were obtained after a multi-step procedure (Loureiro et al. 2005). Firstly, $10 \mathrm{~mL}$ of the air-dried and sieved $(<2 \mathrm{~mm})$ soil was mixed with $40 \mathrm{~mL}$ of distilled water $\left(18.2 \mathrm{M} \Omega / \mathrm{cm}^{2}\right.$ Milli-Q ${ }^{\mathrm{TM}}$ water $)$ and shaken mechanically (150 rpm) for $24 \mathrm{~h}$ in the dark (Loureiro et al. 2005). The suspension was then centrifuged (20 min, $4600 \mathrm{~g}$ ) and filtered through glass microfibre using vacuum filtration apparatus (Whatman GF/C Ø $47 \mathrm{~mm}, 1.2 \mu \mathrm{m}$ porosity). The collected elutriate was divided in half and water extractable metals (Cd-112, Co, Cr-52, Cu, Mn, Ni, Zn-64, P, V, As, Pb-sum) were determined from one half. The other half was processed further to get elutriates for the BioTox ${ }^{\mathrm{TM}}$ test. The concentrations of soluble metals were analysed with inductively coupled plasma mass spectrometry (ICP-MS) in the Almalab of the University of Helsinki. Prior to the ICP-MS analyses, $0.1 \mathrm{~mL}$ concentrated $\mathrm{HNO}_{3}$ was added to $5 \mathrm{~mL}$ elutriates. 
Phytotoxicity to garden cress (L. sativum) was evaluated by the biomass production (root and shoot weight) following the methodology of OECD (2006), with some minor modifications. Seeds were rinsed and imbibited in distilled water for $8 \mathrm{~h}$ prior to planting in $300 \mathrm{~mL}$ pots with moist sample soil (sieved to $<2 \mathrm{~mm}$ ). Fifteen seeds were planted per pot, evenly distributed over the surface of the soil. Each pot was then placed on a Petri dish, to which irrigation water (distilled water) was added daily. The temperature in the cultivation room was $20^{\circ} \mathrm{C}$ and the relative humidity $35 \%$. Samples were illuminated for $16 \mathrm{~h} /$ day with warm fluorescent light of a photon flux density of approximately $100 \mu \mathrm{mol} \mathrm{m} \mathrm{m}^{-2} \mathrm{~s}^{-1}$. Plants were harvested after 21 days. The soil was then carefully removed, and root and shoot parts were separated and rinsed in distilled water prior to drying at $70^{\circ} \mathrm{C}$ for $24 \mathrm{~h}$. Three pots were planted for each landfill and reference soil.

To assess toxicity to bacteria, the BioTox ${ }^{\mathrm{TM}}$ test was performed using freeze-dried $V$. fischeri (strain NRRL B-11177, Aboatox Oy, Finland), which were exposed to elutriates obtained from water extraction of the sample soils. The acidity of the elutriates was adjusted to $\mathrm{pH}$ 6.5-7.0 with a phosphate buffer and the salinity was adjusted to $2 \%$ with sodium chloride $(\mathrm{NaCl})$. Elutriates were stored (max 2 days) at $4^{\circ} \mathrm{C}$ up to the testing time. Luminescence (RLU) was measured before and after 15 min incubation of the bacterial suspension with the sample elutriates, according to the ISO $11348-3$ (1998) standard. The $2 \% \mathrm{NaCl}$ with phosphate buffer addition was used as a control liquid. Toxicity results were expressed as RLU inhibition percent (INH\%). Each analysis was performed on duplicate samples.

$K F=\frac{I C 15}{I C 0}$

$I N H \%=100-\frac{I T 15}{K F \times I T 0} \times 100$

where: 
IC0 $=$ initial luminescence of control sample in RLU

190 IT15 = luminescence intensity of test sample after contact time (15 min) in RLU

191 IT0 = initial luminescence intensity of test sample in RLU

193 In our study, nematodes and enchytraeids were extracted from non-sieved soil samples, as sieving 194 may hurt soil organisms. Glass pieces larger than approximately $4 \mathrm{~mm}$ were, however, gently 195 removed by hand. Nematodes were extracted from 5 to $10 \mathrm{~g}$ and enchytraeids from 30 to $50 \mathrm{~g}$ of 196 fresh soil samples using the wet funnel methods by Sohlenius (1979) and O'Connor (1955), 197 respectively. The number of nematodes and enchytraeids were counted under a binocular198 microscope. In addition, enchytraeids were classified into size classes according to length (0-2, 2$1994,4-6,6-8,8-10,10-12$ and $>12 \mathrm{~mm}$ ), and the total biomass of enchytraeids per sample was 200 calculated according to Abrahamsen (1973). All the nematodes and enchytraeids data were 201 expressed per $\mathrm{g}$ of soil OM. The presence of glass remains, which is a distinctive feature of the 202 landfill soil samples, might inevitably dilute all natural soil components - both minerogenic and 203 organic. By presenting the nematodes and enchytraeids data per g soil OM, these dilution effects are reduced when interpreting toxicity effects.

\section{Statistical analyses}

The normality of data was analysed using Kolmogorov-Smirnov and Shapiro-Wilk tests and the homogeneity of variances with Levene's test. The data were not always normally distributed and the variances were sometimes heterogeneous, and thus the data that required so were log transformed to meet the requirements of parametric tests.

213 The main aim of the study was to explore whether the biological responses (number of nematodes, 214 number and biomass of enchytraeids, luminescence inhibition of $V$. fischeri, and shoot and root 215 growth of L. sativum) differ between glasswork landfills (Johansfors, Kosta, Målerås, Orrefors, 216 Bergdala) and reference sites (Johansfors ref., Kosta ref., Målerås ref., Orrefors ref., Bergdala ref.). 217 Mean values per site based on five replicate soil samples collected from each sampling site were used as tested values. In all analyses concerning soil parameters (total and $\mathrm{H}_{2} \mathrm{O}$ extractable metal concentrations, nutrient concentrations, $\mathrm{pH}, \mathrm{EC}$ ) and biota (plants, number of nematodes per g OM, number and biomass of enchytraeids per g OM), comparisons between landfill and reference sites were performed using a paired sample $t$-test. As the luminescence inhibition of $V$. fischeri data was not normally distributed even after transformation, paired comparisons were performed using the 
non-parametric Wilcoxon's test. In addition, the differences in measured parameters between single glasswork landfills and their nearby reference areas were analyzed using independent $t$-test.

Multiple regression analysis (with stepwise correction) was used to explore whether the abundances of soil fauna within the sites are influenced by measured soil variables. Response variables were the root and shoot biomass of L. sativum, the number of nematodes, and the biomass of enchytraeids. Soil metal and nutrient concentrations, moisture, $\mathrm{OM}, \mathrm{pH}$ and $\mathrm{EC}$ were used as predictor variables. In the regression analyses the five samples per site were used as a replicates despite the fact that they do not represent independent sample units. This makes $25(5 * 5)$ tested values for both glassworks and reference sites (altogether 50 samples). Thus, $p$-values should be considered with caution. All tests were run using IBM SPSS Statistics 23 (SPSS Inc.).

Results

\section{Soil parameters}

Each landfill site was largely contaminated with various metals, as expected. Average concentrations for each sampling site are presented in Table 1, and a more detailed compilation is provided in Supplementary material I. Pb together with $\mathrm{As}, \mathrm{Ba}, \mathrm{Cd}$ and $\mathrm{Zn}$ were the major contaminants, with mean concentrations at all glassworks sites exceeding the guideline values of Swedish legislation for less sensitive land use (Swedish EPA 2009). Also concentrations of Cu and $\mathrm{Sb}$ were found in elevated mean concentrations, exceeding the guideline values for sensitive land use (Swedish EPA 2009). Overall, however, a huge variation in total metal concentrations was observed for the landfill samples, which can be explained by the large heterogeneity of the deposited waste materials: for example, the concentration of $\mathrm{Pb}$ varied from 161 to $38000 \mathrm{mg} \mathrm{kg}^{-1}$,

248 As from 64 to $7790 \mathrm{mg} \mathrm{kg}^{-1}$, Ba from 30 to $3560 \mathrm{mg} \mathrm{kg}^{-1}, \mathrm{Cd}_{\text {from }} 0.2$ to $62.8 \mathrm{mg} \mathrm{kg}^{-1}$, and $\mathrm{Zn}$ 249 from 45 to $1050 \mathrm{mg} \mathrm{kg}^{-1}$ (see Supplementary material I). Nevertheless, considering the whole data 250 set, positive correlations between all the contaminant metals ( $\mathrm{Pb}, \mathrm{As}, \mathrm{Ba}, \mathrm{Cd}, \mathrm{Zn}$ and $\mathrm{Sb}$ ) were observed, implying a common source (the glass waste). Pearson's correlations (two-tailed) were found in the range $0.53-0.88$, with all p-values $<0.001$. As expected, since elevated concentrations are due to disposal of glass waste materials, significantly higher concentrations at the glassworks sites than at the reference areas were also found for all six metals (all t-test, $\mathrm{p}>0.05$ ). 
256 However, only a small part of the analysed total metals were found to be easily water-soluble

257 (Table 2). Of the potential contaminant metals, water-soluble concentrations were determined for $258 \mathrm{As}, \mathrm{Cd}, \mathrm{Pb}$ and $\mathrm{Zn}$ (but not $\mathrm{Ba}$ and $\mathrm{Sb}$ ). $\mathrm{Pb}$ and $\mathrm{As}$ were significantly higher in water extracts from 259 landfill soils than from reference areas ( $t$-test, $p=0.003$ and $<0.001$, respectively), even though 260 only $0.02 \%$ and $0.38 \%$ of the total concentrations were water extractable. At the reference areas, the 261 average concentration of water extractable $\mathrm{Pb}$ was $40 \mu \mathrm{g} \mathrm{kg}^{-1}$ and the corresponding value for As 262 was $201 \mu \mathrm{g} \mathrm{kg}^{-1}$ (Table 2 and Supplementary material II). The water extractable concentrations at 263 the landfill sites were $447 \mu \mathrm{g} \mathrm{kg}^{-1}(\mathrm{~Pb})$ and $989 \mu \mathrm{g} \mathrm{kg}^{-1}(\mathrm{As})$, i.e. concentrations were on average 264 only 11 and 5 times (respectively) higher in water extracts derived from the landfill soils. The 265 average concentration of $\mathrm{Cd}$ in the water extracts was ca 20 times higher in landfill sites (ca $26630 \mu \mathrm{g} \mathrm{kg}^{-1}$ ) compared to reference sites (ca $1.5 \mu \mathrm{g} \mathrm{kg}^{-1}$ ), but due to the high variation the difference 267 was not statistically significant (paired $t$-test, $p=0.113$ ). The concentrations of Zn-64 did not vary 268 between landfill and reference sites (paired $t$-test, $p>0.05$ ), but this was also the metal with the 269 least obvious contamination impact.

271 Comparing the other investigated soil geochemical parameters between the landfill and reference 272 areas, significant differences were observed for $\mathrm{pH}$ in Johansfors (independent $t$-test, $p<0.05$ ). In 273 addition, soil OM and nutrient contents varied between sites but no clear trend was shown (paired $t$ 274 test, $p>0.05$ ) (Table 1). The EC was significantly different, being ca 50\% higher in landfill sites 275 (paired $t$-test, $p=0.003$ ) (Table 1), but overall, the conductivity of all soils was quite low.

277 In summary, although both the basic soil geochemistry and metal concentrations were highly 278 variable, significant differences were seen only for the metal concentrations and EC. 
Table 1. Soil metal and nutrient (N, C, P) concentrations ( $\mathrm{mg} \mathrm{kg}^{-1} ;$ mean \pm standard error; $\left.n=5\right)$ and characteristics at landfill and reference sites. Electric conductivity (EC in $\mathbf{~ m s ~ c m}^{-1}$ and the dry- and organic matter content (DM and OM) in $\mathbf{~ g ~}^{-1}$. The first, and lowest, of the two generic guideline values ( $\left.\mathrm{mg} \mathrm{kg}^{-1}\right)$ of the Swedish EPA (2009) corresponds to the maximum permissible metal concentration in areas with sensitive land use. Concentrations above this level may, among other negative effects, result in negative impacts on soil ecosystem functions. The higher value represents the corresponding figure for land used for industrial purposes (where some reduction in soil functions is accepted). Values in bold highlight metal concentrations that exceed the generic guideline values for sensitive land use.

\begin{tabular}{|c|c|c|c|c|c|c|c|c|c|c|c|}
\hline & Guideline & Bergdala & Bergdala ref. & Johansfors & Johansfors ref. & Kosta & Kosta ref. & Målerås & Målerås ref. & Orrefors & \\
\hline As & $10 / 25$ & $180 \pm 82$ & $3.0 \pm 0.53$ & $2200 \pm 1400$ & $11 \pm 1.2$ & $380 \pm 99$ & $2.5 \pm 0.50$ & $500 \pm 190$ & $8.4 \pm 2.3$ & $\mathbf{1 7 0} \pm \mathbf{3 7}$ & $2.7 \pm 0.49$ \\
\hline $\mathbf{B a}$ & $200 / 300$ & $180 \pm 57$ & $34 \pm 4.8$ & $1300 \pm 640$ & $51 \pm 9.1$ & $470 \pm 88$ & $41 \pm 5.7$ & $1100 \pm 530$ & $91 \pm 15$ & $220 \pm 50$ & $120 \pm 21$ \\
\hline Cd & $0,5 / 15$ & $13 \pm 6.0$ & $0.23 \pm 0.03$ & $4.4 \pm 1.8$ & $0.18 \pm 0.02$ & $6.5 \pm 4.0$ & $0.16 \pm 0.02$ & $5.5 \pm 2.2$ & $0.38 \pm 0.08$ & $19 \pm 11$ & $0.30 \pm 0.30$ \\
\hline$\overline{\mathbf{C u}}$ & $80 / 200$ & $24 \pm 2.7$ & $27 \pm 19$ & $62 \pm 9.1$ & $8.4 \pm 0.48$ & $140 \pm 75$ & $8.4 \pm 1.2$ & $42 \pm 14$ & $21 \pm 2.2$ & $48 \pm 16$ & $16 \pm 1.7$ \\
\hline $\mathbf{P b}$ & $50 / 400$ & $800 \pm 380$ & $19 \pm 2.4$ & $12000 \pm 6900$ & $62 \pm 13$ & $7900 \pm 2100$ & $30 \pm 5.5$ & $1200 \pm 670$ & $100 \pm 26$ & $7000 \pm 2200$ & $45 \pm 12$ \\
\hline $\mathbf{S b}$ & $12 / 30$ & $28 \pm 7.2$ & $0.58 \pm 0.15$ & $6.9 \pm 2.9$ & $1.0 \pm 0.21$ & $31 \pm 5.7$ & $0.41 \pm 0.05$ & $17 \pm 5.9$ & $1.4 \pm 0.34$ & $3.4 \pm 1.0$ & $0.41 \pm 0.03$ \\
\hline $\mathbf{Z n}$ & $250 / 500$ & $330 \pm 100$ & $26 \pm 7.8$ & $430 \pm 180$ & $20 \pm 3.7$ & $350 \pm 42$ & $36 \pm 4.8$ & $340 \pm 85$ & $170 \pm 41$ & $420 \pm 170$ & $72 \pm 7.6$ \\
\hline Tot-P & - & $510 \pm 43$ & $360 \pm 65$ & $3800 \pm 1700$ & $280 \pm 49$ & $1100 \pm 1200$ & $680 \pm 100$ & $3100 \pm 1300$ & $680 \pm 74$ & $420 \pm 80$ & $1800 \pm 240$ \\
\hline Tot-N & - & $3500 \pm 830$ & $2300 \pm 280$ & $1700 \pm 920$ & $2100 \pm 730$ & $3300 \pm 430$ & $2200 \pm 370$ & $1900 \pm 370$ & $2800 \pm 360$ & $700 \pm 290$ & $2900 \pm 200$ \\
\hline Tot-C & - & $73000 \pm 19000$ & $35000 \pm 5900$ & $42000 \pm 25000$ & $57000 \pm 23000$ & $82000 \pm 1400$ & $32000 \pm 4200$ & $68000 \pm 14000$ & $47000 \pm 5600$ & $14100 \pm 4900$ & $40000 \pm 1900$ \\
\hline$C: N$ & - & $21 \pm 0.56$ & $15 \pm 1.1$ & $24 \pm 1.3$ & $27 \pm 1.5$ & $25 \pm 2.6$ & $14 \pm 1.1$ & $36 \pm 12$ & $17 \pm 0.31$ & $20 \pm 5.2$ & $14 \pm 0.64$ \\
\hline $\mathbf{E C}$ & - & $0.12 \pm 0.01$ & $0.04 \pm 0.01$ & $0.09 \pm 0.02$ & $0.04 \pm 0.01$ & $0.10 \pm 0.02$ & $0.06 \pm 0.01$ & $0.14 \pm 0.01$ & $0.07 \pm 0.01$ & $0.06 \pm 0.01$ & $0.05 \pm 0.01$ \\
\hline DM & - & $0.85 \pm 0.02$ & $0.86 \pm 0.02$ & $0.91 \pm 0.04$ & $0.82 \pm 0.02$ & $0.79 \pm 0.02$ & $0.88 \pm 0.02$ & $0.78 \pm 0.03$ & $0.82 \pm 0.02$ & $0.90 \pm 0.02$ & $0.86 \pm 0.01$ \\
\hline$\overline{O M}$ & - & $0.13 \pm 0.03$ & $0.06 \pm 0.01$ & $0.10 \pm 0.07$ & $0.09 \pm 0.02$ & $0.11 \pm 0.02$ & $0.06 \pm 0.01$ & $0.11 \pm 0.01$ & $0.07 \pm 0.02$ & $0.02 \pm 0.01$ & $0.06 \pm 0.003$ \\
\hline pH & - & $5.9 \pm 0.05$ & $5.9 \pm 0.09$ & $7.1 \pm 0.04$ & $5.3 \pm 0.50$ & $6.2 \pm 0.10$ & $6.0 \pm 0.11$ & $6.7 \pm 0.09$ & $6.7 \pm 0.12$ & $5.9 \pm 0.08$ & $5.9 \pm 0.10$ \\
\hline
\end{tabular}


Table 2. Concentrations of $\mathrm{H}_{2} \mathrm{O}$ extractable metals (mean \pm standard error), expressed per kg dry weight of the soil $\left(\mu \mathrm{g} \mathrm{kg}^{-1}\right)$.

Plant and microbe toxicity

In the plant toxicity test with L. sativum, the results varied greatly between sampling sites. In

294 Bergdala and Orrefors, for example, there was a lack of difference between biomass production of 295 plants growing on soils from the contaminated glassworks areas and those from reference areas 296 (Fig. 2; paired $t$-test, $p>0.05$ ). In Kosta, the plants cultivated in the landfill soil samples had a 297 higher root biomass than those grown in the reference soils (independent $t$-test, $p>0.05$ ) (Fig $2 \mathrm{a}$ ), 298 whereas in Malerås, the shoot biomass of plants growing in soil from the landfill was reduced 299 (independent $t$-test, $p<0.05$ ) (Fig $2 \mathrm{~b}$ ). When analysing all sites together, no difference between 300 landfill and reference sites were observed. The same results applied both to the shoot biomass and 301 the root biomass (paired $t$-test, $p=0.933, p=0.384$ ).

303 However, regression analysis showed a positive correlation between shoot weight and soil $\mathrm{H}_{2} \mathrm{O}-\mathrm{Pb}$ $304\left(R^{2}=0.300, F=13.047, p=0.028\right)$ and P concentrations $\left(R^{2}=0.519, F=9.018, p=0.030\right)$. 
a

306

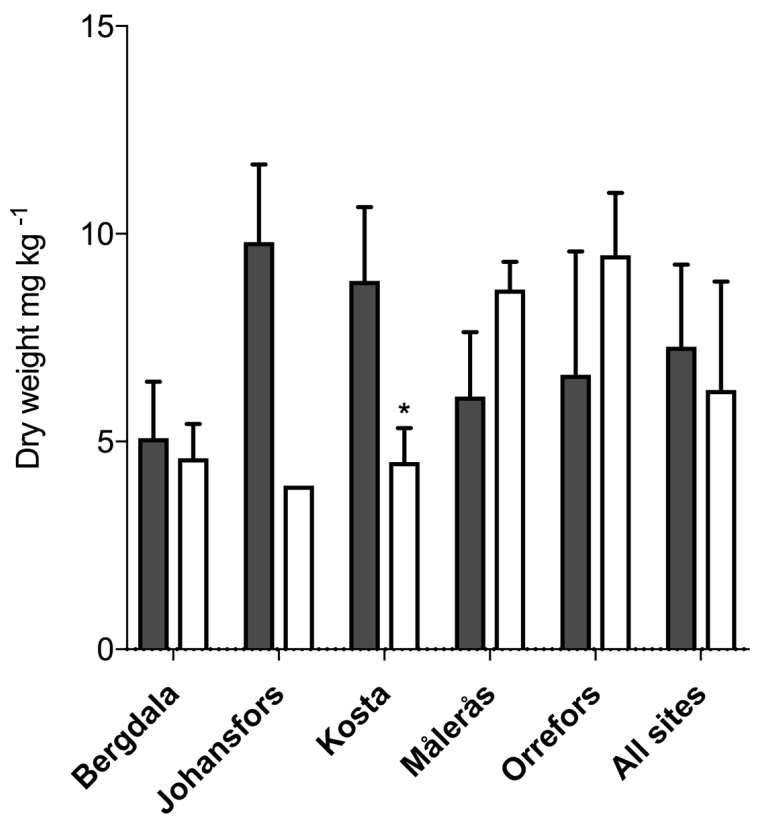

b

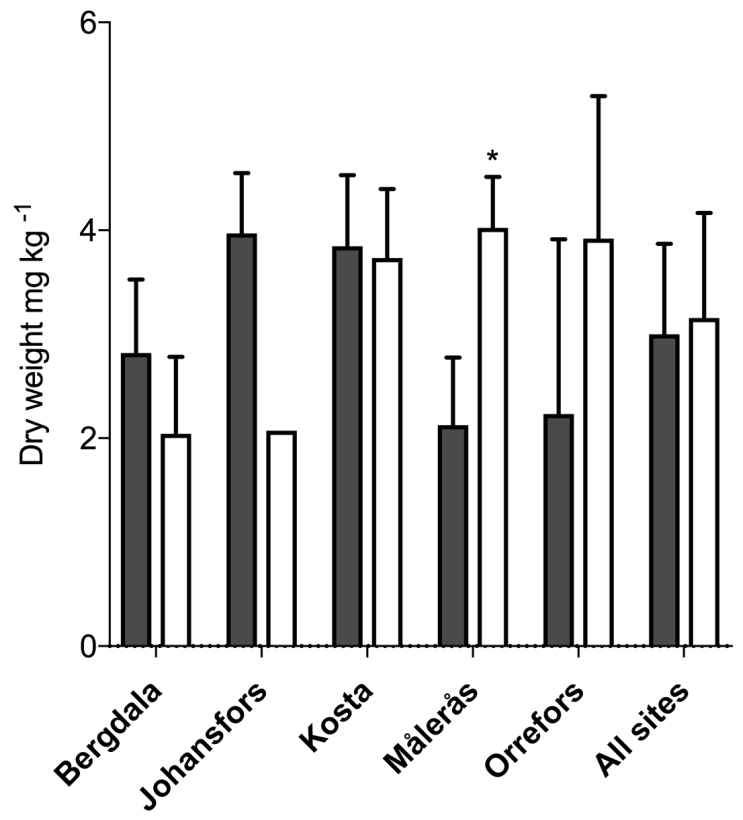

Fig. 2. Biomass production of a) roots and b) shoots of L. sativum at the soils from the glassworks landfill areas (grey) and those from reference areas (white). Each column represents mean values of five samples (with \pm standard error bars, $n=5$ ). An asterisk denotes statistical significance between the glassworks soil samples and reference samples $(\mathrm{p}<0.05)$.

Table 3. Results of linear regression analysis (Stepwise model).

\begin{tabular}{llllll} 
Variable & Predictors in model & $\boldsymbol{\beta}$ & $\boldsymbol{p}$-value & $\mathbf{R}^{2}$ & $\mathbf{R}$ \\
\hline Number of enchytraeids & $\mathrm{H}_{2} \mathrm{O}-\mathrm{Pb}$ & -0.450 & 0.005 & 0.202 & 0.450 \\
\hline Biomass of enchytraeids & $\mathrm{H}_{2} \mathrm{O}-\mathrm{Pb}$ & -0.408 & $<0.001$ & 0.286 & 0.535 \\
& $\mathrm{H}_{2} \mathrm{O}-\mathrm{As}$ & -0.343 & $<0.001$ & 0.388 & 0.623 \\
\hline \multirow{2}{*}{ Number of nematodes } & Tot- $\mathrm{Pb}$ & -0.279 & 0.050 & 0.078 & 0.279 \\
& $\mathrm{Tot}-\mathrm{As}$ & 0.755 & 0.004 & 0.206 & 0.453 \\
\hline \multirow{2}{*}{ Shoot weight of $L$. sativum } & $\mathrm{H}_{2} \mathrm{O}-\mathrm{Pb}$ & 0.548 & 0.028 & 0.300 & 0.548 \\
& Tot-P & 0.468 & 0.030 & 0.519 & 0.720 \\
\hline
\end{tabular}

In the BioTox ${ }^{\mathrm{TM}}$ tests, the elutriates from both the metal contaminated landfill and reference soils exposed very low toxicity to $V$. fischeri with no differences between reference and landfill sites (Wilcoxon, all sites, $p=0.345$ ). In addition, high variation between sampling sites was observed (Fig. 3). Out of the tested landfill sites, only the landfill soil from Kosta reduced light emission of 
$V$. fisheri in comparison to its reference soil (independent $t$-test, $p=0.038$ ). Both landfill and reference soils from Målerås were biostimulative, increasing the light emission of $V$. fisheri; the soils from the landfill more so than reference soils (independent $p=0.008$ ). No statistically significant correlation between $\mathrm{H}_{2} \mathrm{O}$ extracted metals and $\mathrm{INH} \%$ was shown in the regression analysis (Stepwise model).

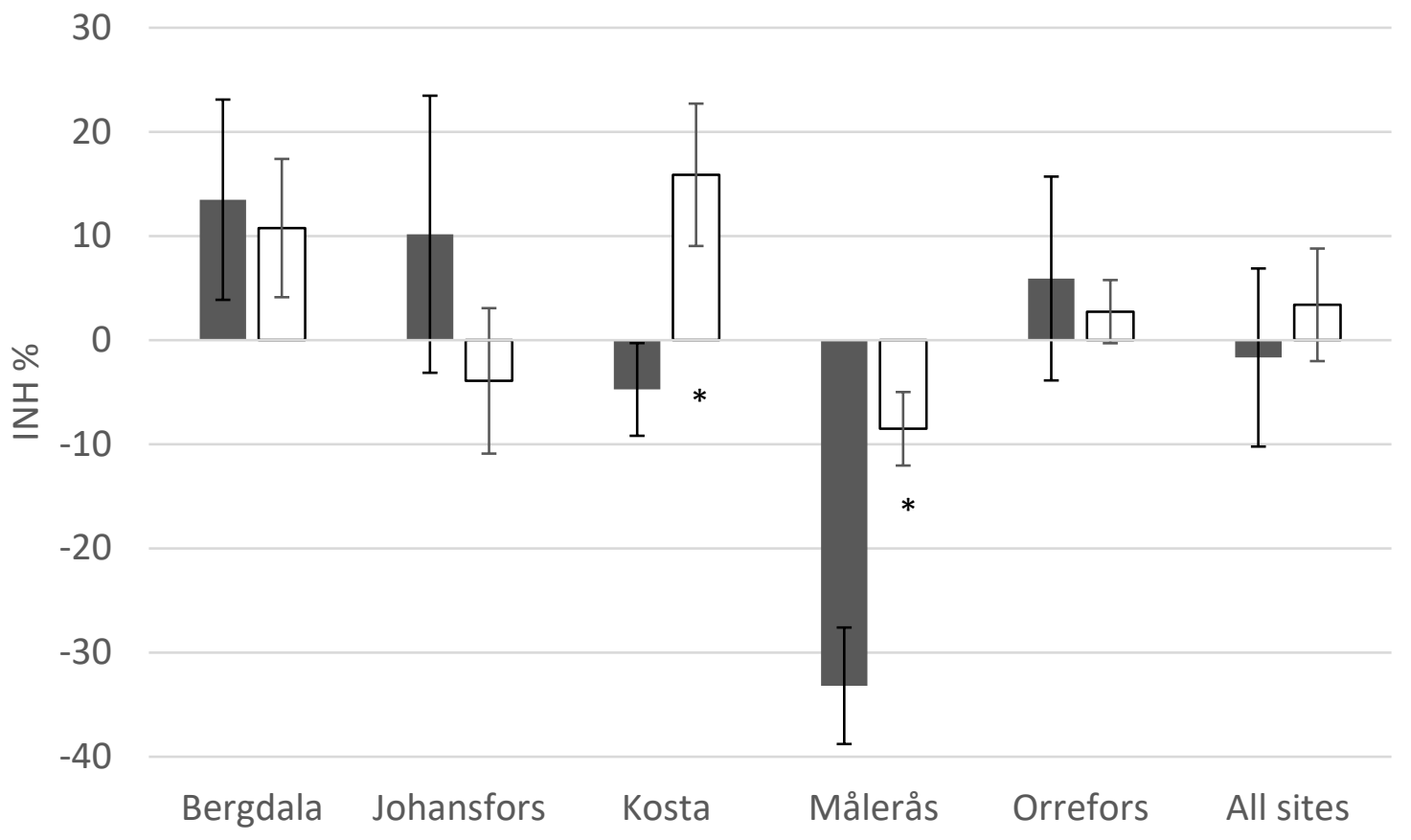

Fig. 3. The luminescence inhibition percent (INH\%) of water elutriates from glassworks landfill soils (grey) and from reference areas (white) for $V$. fischeri. Mean \pm standard error, $\mathrm{n}=5$. Negative values indicate increased light emission/biostimulation. An asterisk denotes statistical significance 334 (with $\mathrm{p}<0.05$ ).

\section{Soil organisms}

339 In the soil samples from the contaminated landfill sites, 13 out of 25 samples were totally lacking 340 enchytraeids. In comparison, only one sample from the reference areas was without enchytraeids. 341 The number and biomass of enchytraeids were significantly reduced in landfill sites of Bergdala, 342 Johansfors and Kosta ( $t$-test, $p<0.05$ ). (Fig. 4). Consequently, the total biomass of enchytraeids 343 (expressed per g OM) was significantly lower in landfill sites (paired $t$-test including all sites, 
$p=0.016$ ), being on average $17.7 \mu \mathrm{g} \mathrm{g}^{-1} \mathrm{OM}$ in the landfill soils and $44.1 \mu \mathrm{g} \mathrm{g}^{-1} \mathrm{OM}$ in the

345 reference soils. Also average biomass of enchytraeid individuals was reduced in glasswork landfill

346 sites (average weight $17.8 \mu \mathrm{g}$ ) compared to reference sites (average $28.1 \mu \mathrm{g}$ ), with the exception of

347 Bergdala (paired $t$-test including Bergdala $p=0.337$, excluding Bergdala $p=0.011$ ).

According to the regression analysis (stepwise; Table 3), none of the following analysed parameters could alone explain the difference in number and biomass of enchytraeids: 1) total concentrations of different metals (neither of $\mathrm{As}, \mathrm{Ba}, \mathrm{Cd}, \mathrm{Pb}, \mathrm{Zn}, \mathrm{Sb}$ or any other of the metals listed in Supplementary material I), 2) total concentrations of nutrients (N, C or P), or 3) soil characteristics ( $\mathrm{pH}$, dry or OM content, EC). The multiple regression analysis showed that $20.2 \%$ and $28.6 \%$ of the observed variation in number and biomass (respectively) of enchytraeids could be explained by $\mathrm{H}_{2} \mathrm{O}-\mathrm{Pb}$ (number: $R^{2}=0.202, F=8.870, p=0.005$ and biomass: $R^{2}=0.286, F=18.425$, $p>0.001$ ). In addition, ca $10 \%$ of reduced enchytraeid biomass can be explained by $\mathrm{H}_{2} \mathrm{O}-\mathrm{As}$ (increase in the coefficient of determination by $10 \% ; R^{2}=0.388, F=14.242, p<0.001$ ).

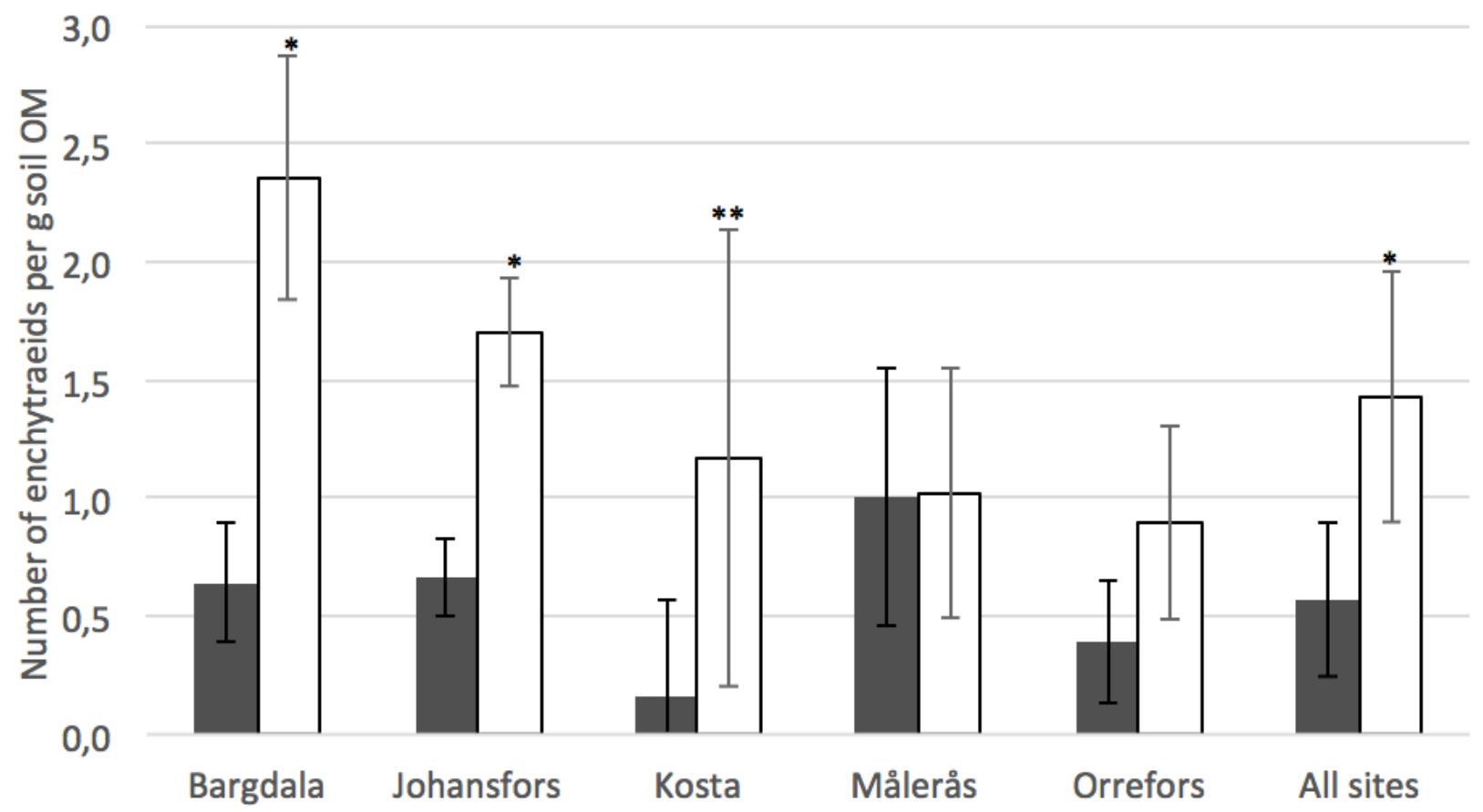

361 Fig. 4. Number of enchytraeids per g soil OM from the glassworks landfill areas (grey) and those from reference areas (white). Mean \pm standard error, $n=5$. Asterisks denote statistical significance ( $*<0.05, * *<0.01)$. 
366 Also the number of nematodes tended to be reduced in the landfill soils, but the difference was statistically significant only in Målerås (independent $t$-test, $p=0.038$; Fig. 5). When analyzing all sites together, no statistically significant difference between landfill and reference soils was observed (paired $t$-test, $p=0.087$ ). The average number of individuals in landfill soils was $54.9 \mathrm{~g}^{-1}$ $\mathrm{OM}$, compared to 74.4 individuals per g OM in reference sites (Fig. 5). According to the regression analysis (Table 3), 27.9\% of the observed variation in the numbers of nematodes could be explained by tot- $\mathrm{Pb}\left(R^{2}=0.078, F=4.060, p=0.050\right)$. In addition, $22 \%$ of the reduction in nematode numbers could be explained by tot-As (increase in the coefficient of determination $R^{2}=0.276$, $F=6.084, p=0.004)$.

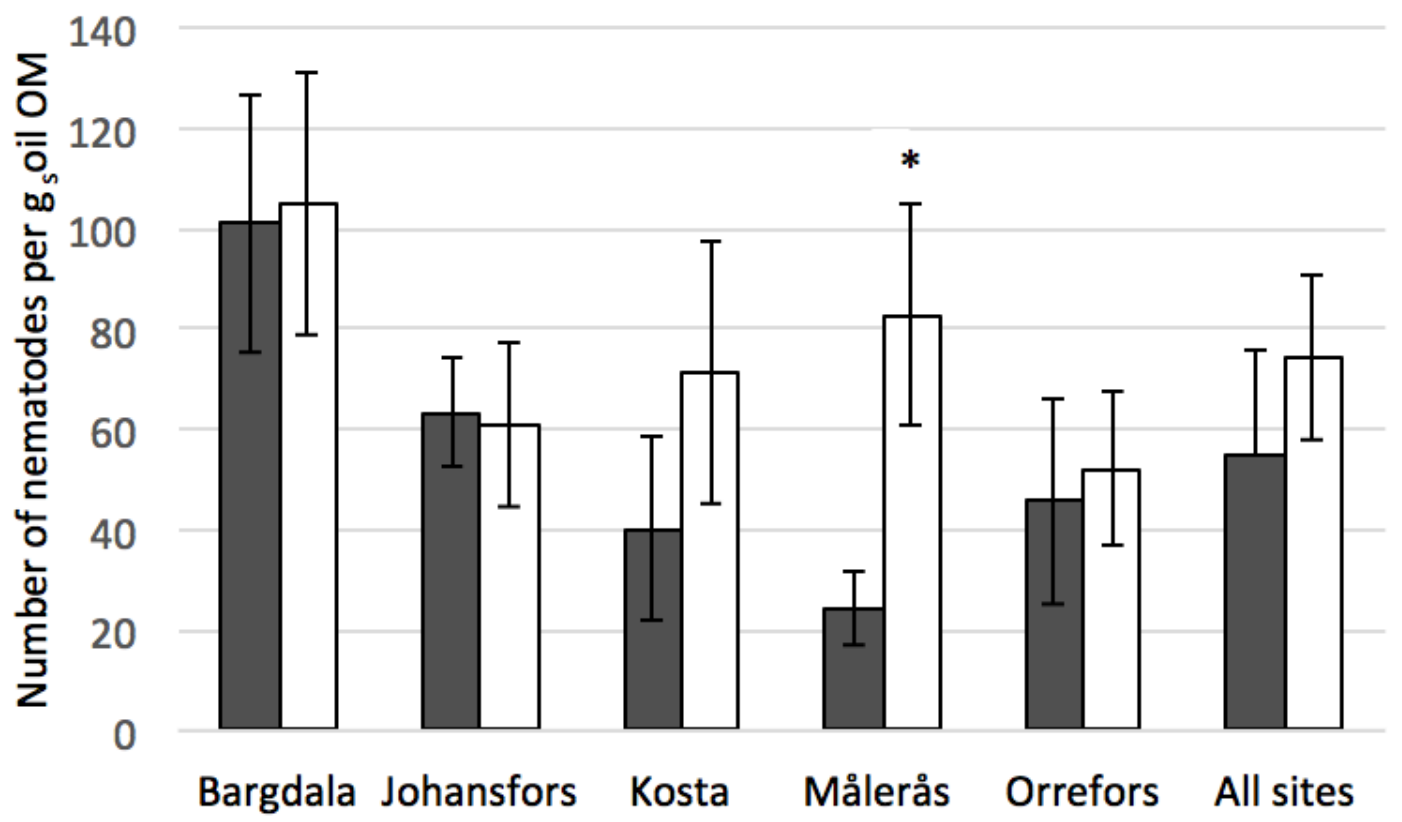

Fig. 5. Number of nematodes per g soil OM from the glassworks landfill areas (grey) and those from reference areas (white). Mean \pm standard error, $n=5$. An asterisk denotes statistical significance (with $\mathrm{p}<0.05$ ). 
The assessment of potential risks to ecological functions and humans living around contaminated sites is a task that is as important as it is complex and challenging. In Sweden alone, there are approximately 85,000 potentially contaminated sites. Since remediation of all these sites is not feasible in the near future, addressing the national goal of a non-toxic environment requires understanding of actual risks for humans and ecosystems around contaminated sites. One way of achieving this, in Sweden as well as elsewhere, may be to include relevant biotests in generic risk assessment methodologies. Several studies have shown that biotests give a better indication of metal bioavailability and ecological risks than chemical analyses alone (Kahru et al. 2005; Zhang et al. 2013). The tests used and evaluated in the present study have all been proven useful in other studies:

Firstly, the biomass production (root and shoot weight) of garden cress (L. sativum) has been found a suitable indicator for the evaluatiton of potential phytotoxicity to vascular plants due to its welldocumented sensitivity to metal contaminants (Baderna et al. 2015; Gill et al. 2012; Montvydiene and Marciulioniene 2004; Vasile et al. 2013). Secondly, the measurement of luminescence inhibition in $V$. fischeri by the BioTox ${ }^{\mathrm{TM}}$ method is a well established and standardized approach. Briefly, the metabolic pathway responsible for light emission by the bacterium is intrinsically linked to cellular respiration, and any disruption of normal cellular metabolism causes a decrease in light production (Parvez et al. 2006). Finally, enchytraeid worms (mostly omnivorous) and nematodes (covering several trophic positions) are often selected as test biota for toxicity tests (Kapusta and Sobczyk 2015). They are present in a wide range of ecosystems, occur abundantly, play a key role in the functioning of soil ecosystems, are easy to use, collect and culture, come into contact with a variety of stress factors (the soil solution, the solid phase, and the gaseous phase in soil), and are sensitive to environmental stresses (Didden and Römbke 2001; Römbke and Moser 2002). The indicator capacity of enchytraeids and also nematodes has been proved in several laboratory (Didden and Römbke 2001) and field experiments (Hui et al. 2009; Höss and Williams 2009;

417 When applied to the five glassworks sites of this study and their reference sites, we saw that the 418 different tests were not consistent, and that there was a large variability between sites. For example, 419 the number of enchytraeids and nematodes was consistently lower at the landfill areas (Fig 4+5), 420 indicating in-situ toxicity to soil inhabiting organisms. But the L. Sativum biomass production (Fig 
2) and luminescence inhibition in $V$. fischeri (Fig. 3) were higher at some of the glassworks sites compared to the corresponding reference sites and lower at others, resulting in no overall statistical difference. Similar site specific inconsistencies between different tests were observed by

424 Karjalainen et al. (2009) regarding CCA-contaminated soil samples. Thus, our results clearly 425 demonstrate that risk assessments of contaminated sites are often complicated due to several 426 influencing factors in the field.

\section{Chosing relevant biotests for assessing soil toxicity}

Most previous studies have focused on the impact of single pollutants (Kapusta and Sobczyk 2015).

431 In reality, many contaminated sites are affected by mixtures of pollutants. Considering landfill sites, 432 the composition of the waste material may also be quite different even in two adjacent soil volumes 433 - something which was clearly manifested by the large variability in, for example, total metal 434 concentrations at single landfill sites of our study. In addition, different subsamples - even from the 435 same site - may differ substantially when it comes to basic geochemical properties (i.e. redox 436 pontial, $\mathrm{pH}$, average grain size, content of sorbants such as organic particles or $\mathrm{Al} / \mathrm{Fe} / \mathrm{Mn}$ 437 hydroxides). Large variabilities between subsamples regarding leachability/bioavailability and 438 toxicity are therefore to expect. From such a perspective, the consistent decline in enchytraeid and 439 nematode abundance and size constitutes a relatively robust indication of the toxic properties of the 440 glassworks soils, despite the low number of samples analyzed. The lack of measurable effects using 441 the acute toxicity tests with bacteria and plants, however, indicated that these tests were not 442 appropriate for the studied environment. As concluded by Waara et al. (2009), the detectability of 443 toxicity in challenging environments depends on site specific conditions and the test organism 444 chosen.

Toxicity not implied by $V$. fisheri or L. sativum

One possible explanation for the lacking inhibition in both $V$. fisheri luminescence and in L. sativum growth is obviously that the glassworks soils don't leach metal contaminants to such a degree that the soil pore water becomes toxic enough. In favor of this hypothesis are the results which showed a 
connection observed between soil metal contamination (in particular of $\mathrm{Pb}$ ) and shoot growth of

456 L. sativum was contrary to what would be expected if soil contamination was limiting plant growth.

457 However, the increase in shoot weight at moderately elevated bioavailable concentrations is 458 probably due to the hormesis effect. Hormesis, which is a dose-response relationship that is 459 characterized by low-dose stimulation and high-dose inhibition, has previously been observed in 460 plants growing on metal contaminated soils (Wang et al. 2010; Calabrese and Blain 2009). Baderna 461 et al. (2015), for example, investigated the phytotoxicity of different metals ( $\mathrm{As}, \mathrm{Cd}, \mathrm{Cr}, \mathrm{Pb}, \mathrm{Hg}, \mathrm{Ni}$ 462 and $\mathrm{Zn}$ ) alone and in mixtures using L. sativum and two others plants, and found a clear hormesis 463 dose-effect relationship. As they highlighted, the biostimulation observed at moderately elevated 464 bioavailable concentrations may be a potential alert flag because it could be the initial adaptive response to low doses of one or several toxicants, where the initial stimulation could turn into 466 strong toxicity at longer exposure times or higher toxicant doses.

Regarding the lacking effect on $V$. fisheri luminescence, the first important note to make is that water extracts produced in batch leaching tests may not adequately mirror the true pore water composition of the site under investigation. Dissolved metal concentrations may be significantly higher in the field (Petänen et al. 2001; Petänen and Romantschuk 2003), for example due to longer contact times and lower L/S ratios. In addition, while the leachability was low with distilled water in our study, a sequential extraction of samples from the fine fraction $(<2 \mathrm{~mm})$ of another glassworks landfill of the region showed that $15-35 \%$ of the total $\mathrm{Pb}$ concentrations and $40-60 \%$ of the total $\mathrm{Cd}$ were dissolved in the first step (using $1 \mathrm{M} \mathrm{CH}_{3} \mathrm{COONa}$ ) (Augustsson et al. 2016). This step (at least theoretically) targets metals that are relatively easily assessible; associated with pore water of the fresh soil and including ions that are weakly sorbed by ion exchange and associated with carbonate complexes (Hall et al. 1996; Kersten and Förstner 1989). Beside the uncertainties in the representativety of the water extracts, it has also been found that bacteria may develop resistance in metal-contaminated enviroments. Their suitability as proxies for metal contamination is thus indistinct. For example, tests made at a heavily $\mathrm{Pb}$ contaminated shooting range in southern Finland showed that the frequency of $\mathrm{Pb}$ resistant bacteria increased in metal polluted soils, but that neither the bacterial numbers nor the community profile was significantly altered (Hui et al. 2012). Also plants appeared to be uneffected by the high Pb levels at these sites (Hui et al. 2009, 2011, 2012). When compared to laboratory experiments of bacterial luminescence inhibition, however, plant growth experiments (direct exposure) have been suggested much more sensitive in assessing soil toxicity (Alvarenga et al. 2008). In tests using Hg- and As-sensing bacteria, the conclusion made by Petänen and Romantschuk (2003) was that some soil bacteria mobilize heavy metals, 
which means that soil animals ingesting these bacteria, like enchytraeids and nematodes, could become exposed. While soil microbes become resistant to heavy metals and plants are able to close them out from the root tissue, soil fauna that ingest detritus including bacterial and fungal cells become exposed to heavy metals in their food. That is another possible explaintion for the response seen in enchytraeids (and nematodes), and the lack of such in our indicator bacteria.

\subsection{Toxicity implied by enchytraeids and nematodes}

It has, reasonably, been argued that the most relevant risk assessment should be based on the evaluation of effects in soil organisms that are exposed to contaminants in their real habitats (Markert et al. 2003). In situ risks are always affected by a cascade of factors (such as soil texture, geochemistry, and hydrology) that may mitigate or amplify the negative effects from contaminants.

The observed low in situ frequency and decreased biomass of enchytraeids (and nematodes) in the metal contaminated soils compared to reference soils, imply that the decomposer community did suffer from the heavy metal contamination. In our case, where we didn't reach the same conclusion from the tests with $V$. fisheri and L. sativum, it may be that enchytraeids and nematodes are more sensitive in general, or simply that they give a better reflection of the true field conditions. While the hormesis effect may complicate the interpretation of $L$. sativum experiments and soil bacteria may develop tolerance against high metal concentrations, previous studies agree on enchytraeids being sensitive to metal contamination (Salminen et al. 2001a, b; Hui et al. 2009), in particular to $\mathrm{Pb}$ (Didden and Römbke 2001). For example, Karjalainen et al. (2009) and Selonen (2015) observed reduced numbers of enchytraeids and nematodes extracted from metal contaminated soils compared to similar pristine forest soil in southern Finland. Also Haimi and Mätäsniemi (2002) showed that close to a metal emission source in central Finland the numbers of enchytraeids and nematodes were clearly decreased. Even though much of the $\mathrm{Pb}$ is relatively immobile, high tot- $\mathrm{Pb}$ concentrations may still be harmful to soil organisms (Selonen et al. 2012). Such an effect is suggested in our study too, since the multiple regression analysis showed a connection between soil $\mathrm{H}_{2} \mathrm{O}-\mathrm{Pb}$ and also $\mathrm{H}_{2} \mathrm{O}-\mathrm{As}$ and the numbers and biomass of enchytraeids. Also, reduced numbers of nematodes seems to be dependent on the concentrations of $\mathrm{Pb}$ and $\mathrm{As}$ in the soil. As the metals at the glassworks sites occur as complex mixtures with variable/covariable metal concentrations, we cannot determine the effect of each metal separately. Furthermore, since the concentrations of single metals had quite low explanatory power on the observed changes, the effect seen is probably a result of multiple stressors having an additive effect. One possible explanation for the larger 
impact seen on enchytraeids than nematodes may be that the summer of 2015 was unusually dry in

524 south-eastern Sweden. Enchytraeids are more sensitive to changes in soil moisture than nematodes 525 are (Lindberg et al. 2002), and the dry conditions may have increased the enchytraeids' sensitivity 526 also for other environmental stress factors.

528 To sum up, the enchytraeids and nematodes were in this study found to be the most reliable 529 bioindicator species. We suggest therefore - in line with Kapusta and Sobczyk (2015) - that 530 enchytraeid and nematode worm density and biomass are to be used as a proxies of soil quality in 531 metal polluted soils together with chemical analyses of the total and 'bioavailable' fraction.

\section{Conclusions}

534 In understanding health and environmental risks at contaminated sites, the issues of bioavailability 535 and toxicity are of key relevance. Despite high total concentrations of several toxic metals 536 (primarily $\mathrm{Sb}, \mathrm{As}, \mathrm{Ba}, \mathrm{Cd}, \mathrm{Pb}$ and $\mathrm{Zn}$ ) at five examined glassworks sites in south-eastern Sweden, 537 the toxicity of the glassworks soils was not revealed by indirect tests; inhibition of light emission by $538 V$. fischeri could not be seen, nor was an effect seen on the growth of L. sativum. That the soils can 539 be toxic to organisms was, however, shown by the decrease in enchytraeid abundance and biomass 540 in these soils compared to reference soils collected nearby. Direct observation of soil fauna is 541 therefore the better proxy for in situ toxicity. In this case they confirm the results from previous 542 chemical leaching tests of glassworks soils, which have indicated that a significant fraction of the 543 metals may be available for biological uptake. The confirmation of in situ bioavailability to soil544 inhabiting organisms also motivates additional studies of the risk posed to humans of the glassworks villages, who consume local foodstuffs and/or drink water from private wells.

\section{Acknowledgement}

548 We thank Juha Mikola (Department of Enviromental Sciences, University of Helsinki, Lahti, 549 Finland) for advice on the statistical analyses and Jukka Pellinen (Almalab) for participation in 550 chemical analyses. The work was supported by the Faculty of Health and Life Sciences at Linnaeus 551 University, Kalmar, Sweden. 
554 Supplementary material I. Concentrations (minimum, median and maximum values) of total 555 metals $\left(\mathrm{mg} \mathrm{kg}^{-1}\right)$ in the studied glass landfill sites.

\begin{tabular}{|c|c|c|c|c|c|c|}
\hline & & Bergdala & Johansfors & Kosta & Målerås & Orrefors \\
\hline \multirow[t]{3}{*}{ As } & $\min$ & 76.4 & 96.6 & 228 & 64.1 & 73.9 \\
\hline & $\max$ & 503 & 7790 & 764 & 1180 & 241 \\
\hline & median & 96 & 473 & 300 & 331 & 228 \\
\hline \multirow[t]{3}{*}{$\mathrm{Ba}$} & $\min$ & 67.3 & 30.2 & 188 & 337 & 94.1 \\
\hline & $\max$ & 393 & 3560 & 668 & 3110 & 384 \\
\hline & median & 143 & 1350 & 435 & 416 & 197 \\
\hline \multirow[t]{3}{*}{ Cd } & $\min$ & 3.3 & 0.2 & 1.7 & 1.6 & 1.3 \\
\hline & $\max$ & 36.7 & 8.2 & 22.4 & 13.9 & 62.8 \\
\hline & median & 9.9 & 5.2 & 2.3 & 3.8 & 10.0 \\
\hline \multirow[t]{3}{*}{ Co } & $\min$ & 1.4 & 3.2 & 3.9 & 0.7 & 1.2 \\
\hline & $\max$ & 3.7 & 7.9 & 6.2 & 8.6 & 5.7 \\
\hline & median & 2.2 & 5.4 & 4.9 & 2.9 & 2.8 \\
\hline \multirow[t]{3}{*}{$\mathrm{Cr}$} & $\min$ & 4.4 & 3.5 & 8.0 & 3.6 & 2.9 \\
\hline & $\max$ & 39.9 & 18.0 & 31.1 & 12.9 & 7.1 \\
\hline & median & 6.2 & 14.2 & 12.7 & 7.3 & 5.8 \\
\hline \multirow[t]{3}{*}{$\mathrm{Cu}$} & $\min$ & 16.4 & 31.4 & 39.3 & 15.6 & 17.3 \\
\hline & $\max$ & 32.1 & 79.8 & 430 & 89.4 & 108 \\
\hline & median & 24.0 & 68.2 & 54.5 & 26.7 & 30.8 \\
\hline \multirow[t]{3}{*}{$\mathrm{Hg}$} & $\min$ & $<0.1$ & $<0.1$ & 0.4 & $<0.1$ & $<0.1$ \\
\hline & $\max$ & $<0.1$ & $<0.1$ & 0.9 & - & $<0.1$ \\
\hline & median & $<0.1$ & $<0.1$ & 0.5 & 2.0 & $<0.1$ \\
\hline \multirow[t]{3}{*}{$\mathrm{Ni}$} & $\min$ & 2.8 & 2.7 & 7.1 & 1.4 & 1.8 \\
\hline & $\max$ & 6.9 & 19.8 & 15.0 & 22.9 & 7.4 \\
\hline & median & 4.2 & 8.5 & 11.1 & 7.2 & 4.7 \\
\hline \multirow[t]{3}{*}{$\mathrm{Pb}$} & $\min$ & 161 & 981 & 4520 & 539 & 1530 \\
\hline & $\max$ & 2030 & 38000 & 16000 & 4210 & 13000 \\
\hline & median & 263 & 4480 & 6240 & 1290 & 6480 \\
\hline \multirow[t]{3}{*}{$\mathbf{V}$} & $\min$ & 6.3 & 7.1 & 10.4 & 1.9 & 2.4 \\
\hline & $\max$ & 19.2 & 14.4 & 21.4 & 18.3 & 10.3 \\
\hline & median & 8.7 & 11.4 & 16.6 & 6.6 & 7.0 \\
\hline \multirow[t]{3}{*}{$\mathrm{Zn}$} & $\min$ & 142 & 45.0 & 197 & 101 & 76.9 \\
\hline & $\max$ & 710 & 1050 & 441 & 589 & 1040 \\
\hline & median & 301 & 422 & 354 & 275 & 419 \\
\hline
\end{tabular}




\begin{tabular}{|c|c|c|c|c|c|c|}
\hline \multirow[t]{3}{*}{$\mathrm{Ag}$} & $\min$ & 0.1 & 0.1 & 0.5 & 0.1 & 0.1 \\
\hline & $\max$ & 0.1 & 3.0 & 1.7 & 0.4 & 0.6 \\
\hline & median & 0.1 & 0.9 & 1.3 & 0.2 & 0.2 \\
\hline \multirow[t]{3}{*}{ Mo } & $\min$ & 0.4 & 0.4 & 1.8 & 0.5 & 0.3 \\
\hline & $\max$ & 0.9 & 2.1 & 5.0 & 1.5 & 1.1 \\
\hline & median & 0.6 & 0.9 & 2.4 & 1.0 & 0.8 \\
\hline \multirow[t]{3}{*}{$\mathrm{Sb}$} & $\min$ & 15.8 & 1.1 & 16.6 & 2.6 & 0.4 \\
\hline & $\max$ & 55.7 & 15.2 & 51.4 & 38.6 & 6.4 \\
\hline & median & 23.2 & 3.7 & 30.2 & 15.4 & 3.8 \\
\hline \multirow[t]{3}{*}{ Sn } & $\min$ & 1.1 & 1.7 & 3.5 & 1.7 & 1.1 \\
\hline & $\max$ & 2.3 & 17.2 & 22.6 & 5.7 & 2.7 \\
\hline & median & 1.6 & 6.0 & 6.0 & 3.9 & 2.0 \\
\hline
\end{tabular}

556 
557 Supplementary material II. Concentrations (minimum, median and maximum values) of $\mathrm{H}_{2} \mathrm{O}$ 558 extractable metals $\left(\mathrm{mg} \mathrm{kg}^{-1}\right)$ in the studied glass landfill soils.

\begin{tabular}{|c|c|c|c|c|c|c|}
\hline & & Bargdala & Johansfors & Kosta & Målerås & Orrefors \\
\hline \multirow[t]{3}{*}{ As } & $\min$ & 0.316 & 0.328 & 0.573 & 0.613 & 0.272 \\
\hline & $\max$ & 1.559 & 1.922 & 3.416 & 2.219 & 0.497 \\
\hline & median & 0.565 & 1.019 & 1.084 & 1.091 & 0.383 \\
\hline \multirow[t]{3}{*}{ Cd-112 } & $\min$ & 0.012 & 0.001 & 0.002 & 0.000 & 0.003 \\
\hline & $\max$ & 0.059 & 0.003 & 0.034 & 0.001 & 0.475 \\
\hline & median & 0.026 & 0.001 & 0.003 & 0.000 & 0.030 \\
\hline \multirow[t]{3}{*}{ Zn-64 } & $\min$ & 0.126 & 0.158 & 0.030 & 0.356 & 0.050 \\
\hline & $\max$ & 0.936 & 1.504 & 0.183 & 0.356 & 1.275 \\
\hline & median & 0.249 & 0.229 & 0.106 & 0.356 & 0.209 \\
\hline \multirow[t]{3}{*}{ Pb-sum } & $\min$ & 0.060 & 0.298 & 0.226 & 0.011 & 0.063 \\
\hline & $\max$ & 0.304 & 1.922 & 0.908 & 0.045 & 1.971 \\
\hline & median & 0.143 & 0.902 & 0.435 & 0.014 & 0.101 \\
\hline
\end{tabular}


Abrahamsen, G. 1973: Studies on body-volume, body-surface area, density and live weight of Enchytraeidae (Oligochaeta). - Pedobiologia 13: 6-15.

Alvarenga, P., Palma, P., Goncalves, A.P., Frnandes, R.M., de Varennes, A., Vallini, G., Duarte, E., Cunha-Queda, A.C. 2008. Evaluation of tests to assess the quality of mine-contaminated soils. Environ Geochem Health 30: 95-99 doi: 10.1007/s10653-008-9147-z.

Augustsson, A., Åström, M., Bergbäck, B., Elert, M., Höglund, L.O., Kleja, D.B. 2016. High metal reactivity and environmental risks at a site contaminated by glass waste. Chemosphere 154: 434-443

Augustsson, A.L.M., Uddh-Söderberg, T.E., Hogmalm, K.J., Filipsson, M.E.M. 2015. Metal uptake by homegrown vegetables - the relative importance in human health risk assessments at contaminated sites. Environ Res 138: 181-190

Baderna, D., Lomazzi, E., Pogliaghi, A., Ciaccia, G., Lodi, M., Benfenati, E. 2015. Acute phytotoxicity of seven metals alone and in mixture: Are Italian soil threshold concentrations suitable for plant protection? Environ Res 140: 102-111

Bergelin, A., Jansson, M., Tapper, M., Bylin, S. 2006. Miljötekniska undersökningar Etapp 1 - 13 Orrefors. Geosigma AB, Uppsala. In Swedish.

Boularbah, A., Schwartz, C., Bitton, G., Morel, J.L. 2006a. Heavy metals contamination from mining sites in south Morocco: 1 . Use of biotest to assess metal toxicity of tailings and soils. Chemosphere 63:802-810. doi: 10.1016/j.chemosphere.2005.07.079

Boularbah, A., Schwartz, C.H., Bittonm G., Aboudrarm W., Ouhammoum A., Morelm J.L. 2006 b. Heavy metal contamination from mining sites in south Morocco: 2. Assessment of metal accumulation and toxicity in plants. Chemosphere 63:811-817. doi: 10.1016/j.chemosphere.2005.07.076

Calabrese, E.J., Blain, R.B. 2009. Hormesis and plant biology. Environ Poll 157: 42-48

Czerniawska-Kusza, I., Kusza, G. 2011. The potential of the Phytotoxkit microbiotest for hazard evaluation of sediments in eutrophic freshwater ecosystems. Environ Monit Assess 179:113121. doi: 10.1007/s10661-010-1722-y.

Didden, W., Römbke, J. 2001. Enchytraeids as indicator organisms for chemical stress in terrestrial ecosystems. Ecotox Environ Safety 50: 25-43.

Dubova, L., Zarina, D. 2004. Application of toxkit microbiotest for toxicity assessment in soil and compost. Environ Toxicol.19 :274-279 doi: 10.1002/tox.20034 
Falk, T., Fredriksson, H., Holmér, G., Johansson, L, G., Lang, M, Sundberg, P. 2005. Boken om glas. 1. Uppl. Växjö: Glafo cop. In Swedish

Fanger, G., Höglund, L.O., Jones, C., Svensson, H. 2004. Undersökning och fördjupad riskbedömning av fem glasbruk i Kalmar och Kronobergs län samt förslag på generell metodik för riskbedömningar vid glasbruk. Kemakta AR 2003-07, Stockholm. In Swedish.

Garcia-Lorenzo, M.L., Martinez-Sanchez, M.J., Perez-Sirvent, C., Molina, J. 2009. Ecotoxicological evaluation for the screening of areas polluted by mining activities. Ecotoxicology 18: 1077-1086. doi: 10.1007/s10646-009-0362-x.

Gill, S.S, Khan, N.A., Tuteja, N. 2012. Cadmium at high dose perturbs growth, photosynthesis and nitrogen metabolism while at low dose it up regulates sulfur assimilation and antioxidant machinery in garden cress (Lepidium sativum L.), Plant Sci 182: 112-120

Haimi, J., Mätäsniemi, L. 2002. Soil decomposer animal community in heavy-metal contaminated coniferous forest with and without liming. Eur J Soil Biol 38: 131-136

Hall, G.E.M., Vaive, J.E., Beer, R., Hoashi, M. 1996. Selective leaches revised, with emphasis on the amorphous Fe oxyhydroxide phase extraction. J Geochem Explor 56: 59-78

Hermelin, C., Welander, E. 1986. Glasboken - Historia, teknik och form, Centraltryckeriet AB, Borås. In Swedish.

Hjortenkrans, D. S. T., Månsson, N. S., Bergbäck, B. G., Häggerud, A.V. 2009. Problems with Sb analysis of environmentally relevant samples. Environ Chem 6: 153-159

Hui, N., Selonen, S., Hanzel, J., Tuomela, M., Rainio, A., Kontio, H., Hakala K., Lankinen, P., Steffen, K., Fingerroos, T., Strömmer, R., Setälä, H., Hatakka, A., Romantschuk, M. 2009. Influence of lead on organisms within the detritus food web of a contaminated pine forest soil. Boreal Environ Res $14: 70-85$

Hui, N., Jumpponen, A., Niskanen, T., Liimatainen, K., Jones, K., Koivula, T., Romantschuk, M., Strömmer, R. 2011. EcM fungal community structure, but not diversity, altered in a $\mathrm{Pb}$ contaminated shooting range in a boreal coniferous forest site int Southern Finland. FEMS Microbiol Ecol 76: 121-132

Hui, N., Liu, X., Kurola, J., Mikola, J., Romantschuk, M. 2012. Lead (Pb) contamination alters richness and diversity of the fungal, but not the bacterial community in pine forest soil. Boreal Environ Res 17: 46-58

Håkansson, K., Ländell, M. 2006. Miljötekniska undersökningar Etapp 1 - 16/17 Kosta Glasbruk och glasbruksdeponi. Geo Innova, Linköping. In Swedish. 
Höss, S., Williams, P.C. 2009. Ecotoxicity testing with nematodes. In book: Wilson, M.S., KakouliSuarte, T. (Ed.) Nematodes as environmental indicators. CAB International, London, Uk. pp208-224

Kahru, A., Ivask, A., Kasemets, K., Llumaa, L., Kurvet, I., Ois, F.M., Dubourguier, H. 2005. Biotests and biosensors in ecotoxicolgical risk assessment of field soils polluted with zinc, lead, and cadmium. Environ Toxicol Chem 24: 2973-2982. doi: 10.1897/05-002R1.1

Kalmar County Administrative Board, 2016. Prioritized contaminated sites in the county. http://www.lansstyrelsen.se/kalmar/sv/miljo-och-klimat/verksamheter-med$\underline{\text { miljopaverkan/ebh/lanets-mest-fororenade-omraden-prioriteringslista/Pages/default.aspx }}$ Assessed April 13/2016.

Kapusta P., Sobczyk Ł. 2015. Effects of heavy metal pollution from mining and smelting on enchytraeid communities under different land management and soil conditions. Sci Total Environ 536: 517-526

Karjalainen, A.M., Kilpi-Koski, J., Väisänen, A.O., Penttinen, S., van Gestel, C.A., Penttinen, O.P. 2009. Ecological risks of an old wood impregnation mill: application of the triad approach. Integr Environ Assess Manag 5: 379-389

Kersten, M., Förstner, U. 1989. Speciation of trace elements in Sediments, In: Batley, G. Ed. , Trace Element Speciation: Analytical Methods and Problems, CRC Press, Boca Raton, FL, pp 245317

Kronoberg County Administrative Board. 2016. Prioritized contaminated sites in the county. http://www.lansstyrelsen.se/kronoberg/sv/miljo-och-klimat/verksamheter-med$\underline{\text { miljopaverkan/fororenade-omraden/prioriterade/Pages/index.aspx?keyword=prioriteringslista }}$ Assessed April 13/2016

Kördel, W., Bernhardt, C., Derz, K., Hund-Rinke, K., Harmsen, J., Peijnenburg, W., Comans, R., Terytze, K. 2013. Incorporating availability/bioavailability in risk assessment and decision making of polluted sites, using Germany as an example. J. Hazard Mater 261: 854-862

Lindberg, N., Engtsson, J.B., Persson, T. 2002. Effects of experimental irrigation and drought on the composition and diversity of soil fauna in a coniferous stand. J Appl Ecol 39: 924-936

Loureiro, S., Ferreira, A., Soares, A., Nogueira, A. 2005. Evaluation of the toxicity of two soils from Jales Mine (Portugal) using aquatic bioassays. Chemosphere 61:168-177 doi: 10.1016/j.chemosphere.2005.02.070.

Magnusson, J. 1971. Glas - Glasets egenskaper och tillverkning, Svenska Reproduktions AB, Stockholm. In Swedish. 
Mamindy-Pajany, Y., Hamer, B., Roméo, M., Géret, F., Galgani, F., Durmisi, E., Hurel, C., Marmier, N. 2011. The toxicity of composted sediments from Mediterranean ports evaluated by several bioassays. Chemosphere $82: 362-369$ doi: 10.1016/j.chemosphere.2010.10.005

Markert, B.A., Breure, A.M., Zechmeister, H.G. 2003. Bioindicators \& Biomonitors, Elsevier Science, Oxford. p. 997

McLaughlin, M.J., Zarcinas, B.A, Stevens, D.P., Cook. N. 2000. Soil testing for heavy metals. Commun Soil Sci Plan 31: 1661-1700

Montvydiene, D., Marciulioniene, D. 2004. Assessment of toxic interactions of heavy metals in a multicomponent mixture using Lepidium sativum and Spirodela polyrhiza. Environ Toxicol 19: $351-358$

Månsson, N., Carlsson, E. 2002. Antimony emissions of concern for the crystal glass industry. Glasteknisk tidskrift 57: 50-53.

Nyqvist, F., Helmfrid, I., Augustsson, A., Wingren, G. 2017. Increased cancer incidence in the local population around metal-contaminated glassworks sites. Accepted for publication in Journal of Occupational and Environmental Medicine.

O'Connor, F. B. 1955. Extraction of enchytraeid worms from a coniferous forest soil. Nature 175: $815-816$

OECD Guidelines for the testing of chemicals 2006. Test No. 208: Terrestrial Plant Test: Seedling

$$
\text { Emergence and Seedling Growth Test, Organization for Economic Cooperation and }
$$
Development Publishing, Paris

Parvez, S., Venkataraman, C., Mukherji, S. 2006. A review on advantages of implementing luminescence inhibition test (Vibrio fischeri) for acute toxicity prediction of chemicals. Environ Int 32: 265-268

Petänen, T., Virta, M., Karp, M., Romantschuk, M. 2001. Construction and use of broad host range mercury and arsenite biosensor plasmids in the soil bacterium Pseudomonas fluorescens OS8. Microb Ecol 41:360-369

Petänen, T., Romantschuk, M. 2003. Measurement of bioavailability of mercury and arsenite using bacterial biosensors. Chemosphere 50: 409-413.

Radojević, M., Bashkin, V.N. 2006. Practical environmental analysis.2nd ed. RSC Publishing, USA, p. 457

Römbke, J., Jänsch, S., Didden, W. 2005. The use of earthworms in ecological soil classification and assessment concepts. Ecotoxicol Environ Safe 62:249-265. doi: 10.1016/j.ecoenv.2005.03.027. 
Römbke, J., Moser, T. 2002. Validating the enchyt1raeid reproduction test: organisation and results of an international ringtest. Chemosphere 46: 1117-1140.

Salminen, J., Anh, B., van Gestel, C. 2001b. Indirect effects of zinc on soil microbes via a keystone enchytraeid species. Environ Toxicol Chem 20: 1167-1174

Salminen, J., van Gestel, C. A., Oksanen, J. 2001a. Pollution-induced community tolerance and functional redundancy in a decomposer food web in metal-stressed soil. Environ Toxicol Chem. 20: 2287-2295

Selonen, S. 2015. The fate and effects of lead $(\mathrm{Pb})$ at the active and abandoned shooting ranges in a boreal forest ecosystem. Doctoral Thesis. Reports from the department of Environmental Sciences, Lahti. University of Helsinki. Unigrafia, Helsinki. ISBN 978-951-51-0907-1

Selonen, S., Liiri, M., Setälä, H. 2014. Can the soil fauna of boreal forests recover from leadderived stress in a shooting range area? Ecotoxicology 23:437-448

Selonen, S., Liiri, M.m, Strömmer, R., Setälä, H. 2012. The fate of lead at abandoned and active shooting ranges in a boreal pine forest. Environ Tox Chem 31: 2771-2779

SGU (Swedish Geological Survey). 2014. Geokemisk atlas över Sverige. In swedish.

SMHI (Swedish Meteorological and Hydrological Institute). 2016. Meteorological data online. http://opendata-download-metobs.smhi.se/ Assessed May 24, 2016

Sohlenius, B. 1979. A carbon budget for nematodes, rotifers and tardigrades in a Swedish coniferous forest soil. Holarctic Ecol 2: 30-40

Swedish EPA (Environmental Protection Agency). 2009. Report 5976, Riktvärden för förorenad mark. In Swedish.

Uddh-Söderberg, T.E., Gunnarsson, S.J., Hogmalm, K.J., Lindegård, MIBG., Augustsson, ALM. 2015. An assessment of health risks associated with arsenic exposure via consumption of homegrown vegetables near contaminated glassworks sites. Sci Total Environ 536: 189-197

Vasile, L.P., Sobariu D.L., Diaconu M., Statescu F., Gavrilescu M. 2013. Effects on heavy metals on Lepidium sativum germination and growth. Environ Eng Manage J 12: 727-733

Waara, S., Farm, C. 2008. An assessment of the potential toxicity of runoff from an urban roadscape during rain events. Environ Sci Poll Reserch 15: 205-210

Wang, C-R., Tian, Y., Wang, X-R., Yu, H-X., Lu, X-V., Wang, C., Wang, H. 2010. Hormesis effects and implicative application in assessment of lead-contaminated soils in roots of Viciafaba seedlings. Chemosphere 80: 965-971

Werkelin, D., Gustavsson, S. 2006. Miljötekniska undersökningar Etapp 1 - Objekt 03 - Johansfors Glasbruk, Emaboda. Kalmar län. PentaCon, Visby. In Swedish. 
724 Zhang, X., Wang, X., Wei, D., Li, B., Ma, Y., Huang, Z. 2013. The influence of soil solution 725 properties on phytotoxicity of soil soluble copper in a wide range of soils. Geoderma 211-2012: 726 $1-7$

727 